\title{
THE HANDLING, TRANSPORTATION, AND STORAGE OF PERISHABLE FOODSTUFFS.*
}

A Review of the Work of the Food Research Laboratory, Bureau of Chemistry, U. S. Department of Agriculture.

(Contribution from the Food Research Laboratory, Burean of Chemistry, U. S. Department of Agriculture.)

BY

JOSEPH SAMUEL HEPBURN, A.M., M.S.

PART II,

The Scientific Stumy of the Handuing of Prishable Foodstuffs.

COMMERCIAL METHODS I73-SCIENTIFIC INVESTIGATION OF COMMERCIAL METHODS

IN THE FIELD I83-HARD FROZEN POULTRY I86-CHEMICAL CHANGES AND BACTERIAL GROWTH IN MILK AT LOW TEMPERATURES I86STUDIES OF EGGS I89-CONCLUSION I9IBIBLIOGRAPHY ID2.

COMMERCIAL METHODS.

THE study of poultry handling has formed a large part of the work of this laboratory. The various commercial methods of dressing, transporting, storing, and marketing have been studied in the field and have been investigated in the laboratory, in order to learn which methods will produce a bird of the best quality for the consumer.

The eastern portion of the United States does not raise sufficient poultry to supply the demand of its own markets. By far the greater portion of the market poultry of the country is a product of the corn belt. The methods of breeding and feeding chickens have been studied in detail in the Eastern States, with a consequent increase in the quality of the eastern bird; in the corn belt, with its large farms, it has not been possible to study these particular branches of poultry husbandry, therefore in order to obtain a market product which will compete successfully in the eastern markets with fowls from nearby farms in respect

* Presented at the Stated Meeting of the Institute held Wednesday, May 17 , I9II. 
to quality, the western packers have been obliged to place great stress upon the killing, picking, chilling, packing, and transporting of chickens.

In the poultry belt chickens are prepared for market at packing houses. 'The birds may be taken directly from the farm to the slaughter house, or they may be submitted to a fattening process in a feeding station, then be removed to the packing house for slaughter. The killing of chickens is carried out in several ways. In bench killing the beak of the bird is fastened at the lower end of an inclined bench; in string killing the fow

FIG. I.

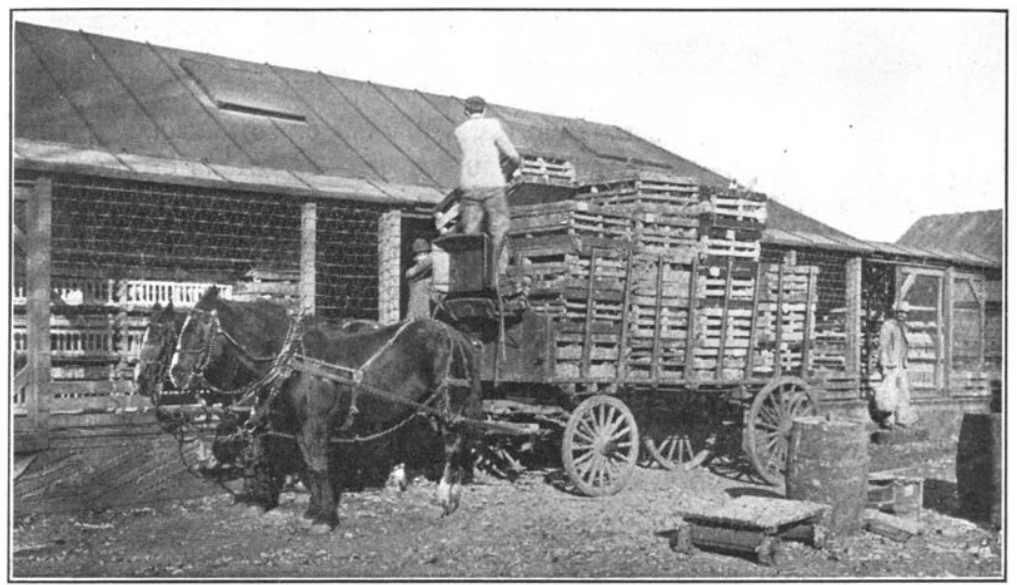

A rrival at the packing house of chickens from the farm.

is suspended by its legs by means of a rope; in either case the bird is killed by means of a knife-cut in the mouth. Other methols of killing exist, thus the bird may be held under the arm while administering the fatal cut, or the neck may be broken by mere muscular force. Since bad bleeding of a chicken leads to more rapid deterioration than occurs in a well-bled bird, an anatomical study has been made of the blood-vessels of the head and neck of the chicken, in order to devise a method of cutting which will insure proper bleeding. Two large veins run the whole length of the neck, one on each side, and are united by a diagonal "bridge vein" which is just below and behind the ear, and is farther front on the left side. This bridge vein lies just beneath the skin of the roof of the mouth and passes directly 
across the $\mathrm{U}$-shaped depression in the skull into which the upper part of the spinal column fits. By cutting the left neck vein and the bridge vein at their junction in the mouth of the chicken, good bleeding is insured. Moreover, the bones of the skull offer a backing to the knife and prevent it from sinking too deep, thus collection of blood in the soft tissues of the neck is prevented. It is interesting to note that at least thirty per cent. of the poultry coming to the New York market is incompletely bled.

The process employed for picking poultry varies. The birds may be scalded in order to loosen the feathers, then picked;

FIG. 2.

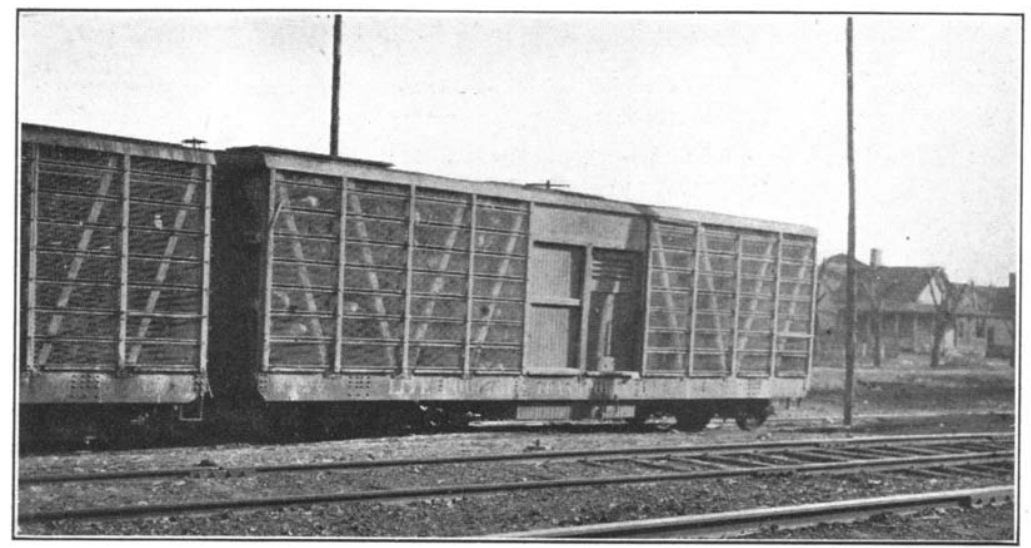

Railroad cars for transportation of live chickens.

since scalding is highly destructive to the structure of the skin, which serves as a protective coat to the carcass, a scalded chicken deteriorates rapidly. If the bird be dry picked, it is not only cut so as to bleed well, but the brain is pierced as well. The knife is run under the eye at such an angle that its point will touch the skull midway between the eyes and a little behind them; or the knife is placed half way down the groove in the roof of the chicken's mouth then thrust upward until it reaches the top of the skull midway between the eyes. The point of the knife is moved backward and forward slightly to destroy enough brain tissue to paralyze the bird, yet not kill it instantly. The resulting paralysis of the feather muscles facilitates dry picking. The rough picking may be done on the killing bench. 
or may be carried out while the bird is suspended by its legs by means of a rope. For the final picking or "pinning" suspension by a rope may be utilized as in killing and rough dressing, or the workmen may hold the birds on their laps during the process. "String" killing, roughing and pinning form the better procedure. During picking, care should be taken to avoid rubbing or tearing the skin, and thus opening the way for bacterial invasion and loss in quality.

FIG. 3 .

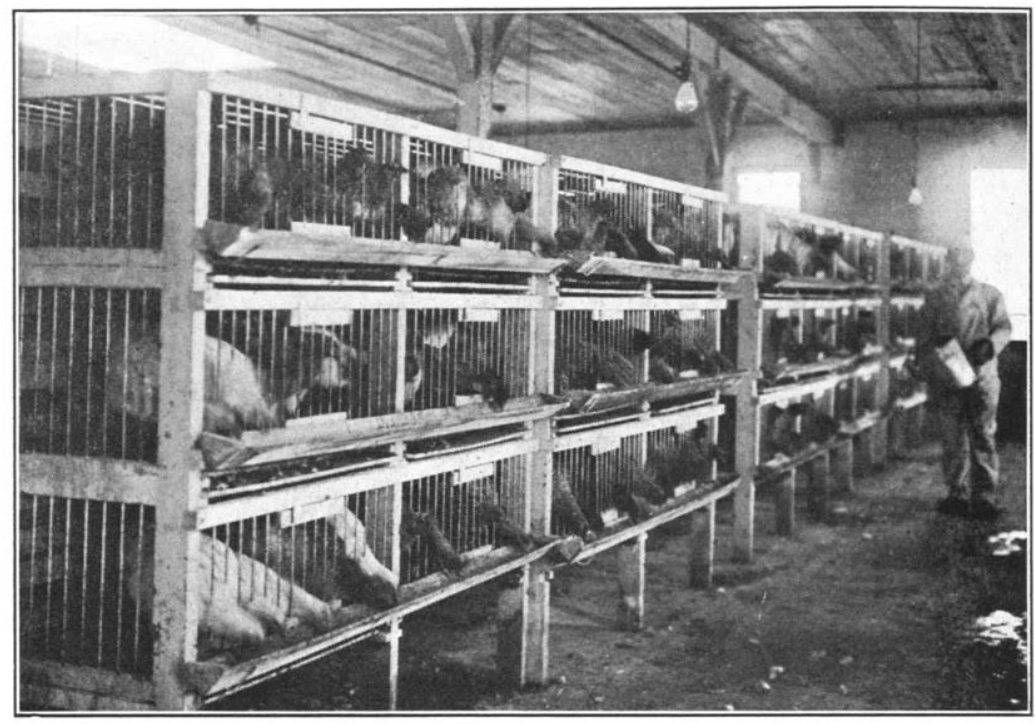

Fnterior of a feeding station-feeding-pens.

The dressed poultry may be cooled in water and packed in cracked ice; or it may be cooled in air in an artificially refrigerated chill room, then packed dry. In the latter procedure, the birds are placed on movable racks and are subjected to a temperature of $35^{\circ}$ to $40^{\circ} \mathrm{F}$. $\left(2^{\circ}\right.$ to $4^{\circ} \mathrm{C}$.) in a chill room, which is provided with mechanical refrigeration, until the greater part of the animal heat has been removed, then they are transferred for the final chilling to a second chill room, the temperature of which is kept below $35^{\circ} \mathrm{F}$. ( $2^{\circ} \mathrm{C}$. $)$, preferably at $30^{\circ} \mathrm{F}$. $\left(-\mathrm{I}^{\circ} \mathrm{C}\right.$.). The packing should be done in the second chill room. The chickens are usually packed in small boxes, each of which 
holds one dozen birds. Broiling chickens are packed with the breast up and the feet hidden, one dozen broilers form a layer and but one layer is placed in a box. Roasting chickens or fowls are laid on their side, six birds form a layer and two layers are placed in a box. The general tendency is to eliminate

FIG. 4.

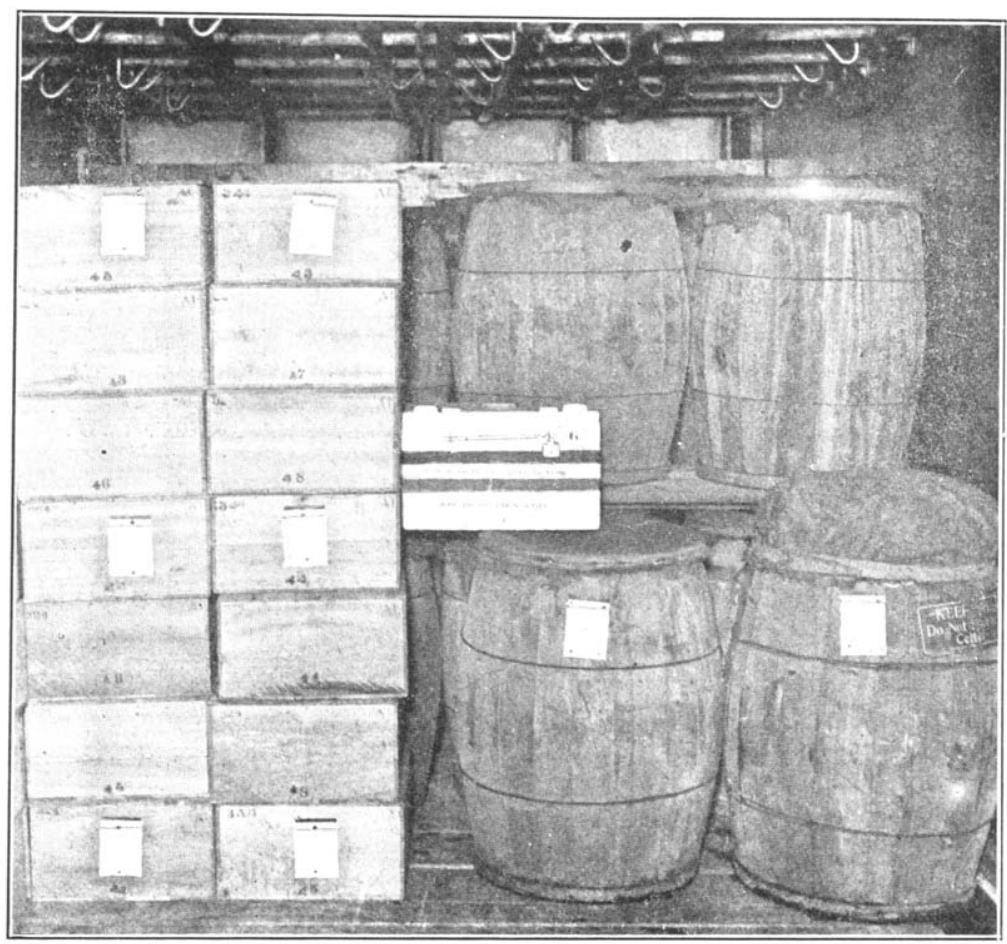

Experimental shipment in a refrigerator car. In the background are the joe bunkers. The boxes on the lefi contain eggs. Two harrels are in the foreground; the one on the .right, in which the contents cause the cover to protrude above the top of the barrel, contains ice-packed chickens: while the one in the centre, with the cover level with the top of the barrel, contains dry-packed chickens. The locked box. which rests on the latter barrel, contains a thermograph.

pressure on the tender tissues of the chicken as far as possible, therefore heads are wrapped in parchment paper and turned back so that they rest against the bony structure, rather than against the soft flesh of the thighs and breast; and the package is maicle smaller and smaller. Fowls are now sometimes packed a single layer to the box, and the carton for the single chicken or at most a pair of chickens is a recent advance which is 
gaining in favor. If the boxes are held for several days before shipment from the packing house, they are kept in the chill room of lowest temperature or are placed in a "freezer" at a temperature of $\mathrm{O}^{\circ}$ to $5^{\circ} \mathrm{F}$. (-I $8^{\circ}$ to $-9^{\circ} \mathrm{C}$.), for from twentyfour to forty-eight hours. When not more than twelve chickens of ordinary size have been packed in a box, a period of fortyeight hours in a good freezer will very thoroughly harden the birds; a number of such boxes in a refrigerator car is a valuable aid in maintaining an equably cold temperature.

The boxes are always transported in refrigerator cars, so that the chickens may be kept at such a temperature for such a period of time, that they will reach the point of consumption in good condition after a railroad haul of one thousand miles or more. The bunkers of refrigerator cars, which are used for the transportation of dry packed poultry, are chilled by means of fine ice mixed with from to to I5 per cent. of salt. This mixture will maintain the temperature of the middle of the car, four feet from the floor, at $40^{\circ} \mathrm{F}$. $\left(4^{\circ} \mathrm{C}\right.$.) or under, provided the car be built with sufficient insulation and be in good order, i.e., have tight-fitting doors, unbroken lining, etc. The boxes containing the most recently killed chickens are placed next the bunkers where the temperature frequently falls to $\mathrm{ro}^{\circ} \mathrm{F}$, $\left(-\mathrm{I} 2^{\circ} \mathrm{C}\right.$. $)$, and where the air about the top layer, 4 feet from the floor, often has a temperature not exceeding $30^{\circ} \mathrm{F}$. $\left(-I^{\circ} \mathrm{C}\right.$. $)$. The boxes which have been in the freezer are packed together as tightly as possible in the central part of the car, and thus serve as a source of cold, where cold is most needed, i.e., in the middle of the car, where refrigeration from the bunkers is least. The height of the load should not exceed four feet from the floor of the car. The cars are inspected and iced at icing stations during the railroad haul.

After poultry has been chilled or frozen the low temperature should be maintained constantly until the product is consumed, for a fluctuation in temperature is accompanied by a condensation of moisture, which creates a favorable environment for the action of bacteria and enzymes, and thus gives rise to decomposition. The wholesale dealer should keep dry packed poultry, between receipt and disbursement, in a mechanically refrigerated chill room at a temperature below $40^{\circ} \mathrm{F} .\left(4^{\circ} \mathrm{C}\right.$. $)$. Frozen poultry should be carried in a room which is kept at a 
temperature below $15^{\circ} \mathrm{F}$. $\left(\rightarrow 9^{\circ} \mathrm{C}\right.$.). The retail dealer usually keeps his stock of chickens in an ice-box, the temperature of which is about $45^{\circ} \mathrm{F}$. $\left(7^{\circ} \mathrm{C}\right.$. $)$. However, even the retailers are beginning to use mechanical refrigeration, by means of which they may keep their poultry at a chill room temperature.

Water cooled chickens are always packed in barrels between layers of ice, and are kept in contact with ice until they reach the retail dealer. The barrels are usually transported in refrigerator cars. The retail dealer generally places his wet- (or ice-) packed chickens in a drained, zinc-lined box and mixes them with fine ice.

Air-chilling and dry packing would seem to offer a better mode of marketing than water-cooling and ice-packing. The latter process is uncleanly, places much pressure on the tender tissue of chicken muscle, and injures the skin, thus opening the way for bacterial invasion. Scientific research has proved the truth of these contentions. A bacteriological study has been made of the skins of chickens chilled in dry air, and in water and ice. After even a short keeping time, as market practices go, a markel preponderance of organisms was found in the skins of the birds which had been cooled in water and ice. The following data show that the acidity of the crude fat of chickens, which is a measure of decomposition, increases more rapidly in water-chilled, ice-packed chickens, than in air-chilled birds kept at $32^{\circ} \mathrm{F}$, in dry air.

\section{Actutty of Fat as an Index of Freshness.}

History of sample.

Acid value.

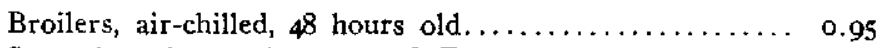

Same lot after 4 days, at $32^{\circ}$ F............... 2.10

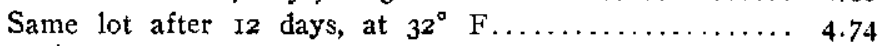

Fow], air-chilled, 8 days at $32^{\circ} \mathrm{F} \ldots \ldots \ldots \ldots \ldots \ldots \ldots \ldots, 65$

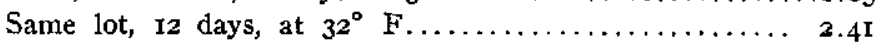

Fowl, kept at $32^{\circ} \mathrm{F}$. for 3 days............ 80

Same lot, kept at $32^{\circ}$ F. for 6 days.............. I.4I

Broilers, water-chilled, ice-packed, 48 hours old...... 0.88

Same lot, 4 days in ice................... 4.57

Same lot, 7 days in ice....................... $4.7 \mathrm{I}$

Fowl, water-chilled, ice-packed, 8 days............ 8.55

Same lot, to days in cracked ice............... 8.86

Fowl, kept in ice 3 days.................... 2.20

Same lot, kept in ice 6 days................ 2.70 
An extensive chenical and bacteriological study is now being made of the marketing of air-cooled, dry-packed chickens and of water-cooled, ice-packed birds.

Dry packed poultry may be either drawn or undrawn. If drawn, the drawing or evisceration may be "full drawn," "wire drawn" or "Boston drawn." In "full drawing" the body cavity is opened by a transverse cut across the abdomen and the vent is removed by cutting around it. The head is cut off and the intestines and viscera are completely removed. The heart, liver, cleaned gizzard and excess body fat are placed in the body cavity. The shanks and feet are removed and the

Fig. 5.

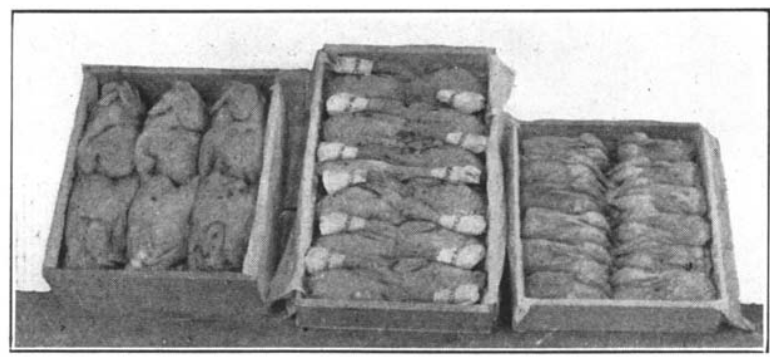

Dressed chickens packed in boxes, one layer to the box. On the left, roasters, six birds to a layer, packed on their sides. In the centre, broilers, twelve birds to a layer, "squatted" i.e., packed with their backs up, and their heads and necks laid across the opposite birds, On the right, broilers, twelve birds to a layer, packed with their breasts up and their necks, heads and feet hidden.

hocks are thrust through the opening in the abdomen and the vent.

" "Wire" drawing consists in pulling out a loop of intestine by inserting the finger through the vent; cutting the loop, and drawing out the gut by careful traction until it breaks at the gizzard. The vent of a bird so drawn presents a normal appearance; the only indication of drawing is the collapsed abdomen.

"The 'Boston' drawing is a modification of the 'wire' in that a circular incision is made around the vent and the intestines pulled through until rupture occurs at the gizzard." The undrawn fowls are shipped with heads and feet on, and no incisions are made except for bleeding and braining.

Full drawn poultry decomposes the most rapidly during the interval between dressing in the packing house and final sale by the retailer in the city; Boston drawn and wire drawn birds 
decompose less rapidly than the full clrawn chickens, but more rapidly than the undrawn; the wire drawn birds usually suffer less decomposition than the Boston drawn. Undrawn poultry decomposes more slowly than that which has been entirely or partially eviscerated. These deductions are based on a study of the bacterial content of the wall of the abdominal cavity and on determinations of the acidity of the crude abdominal fat and of the quantity of loosely-bound or ammoniacal nitrogen present in the flesh.

Poultry may be held for weeks in a chill room or may be frozen solid and kept in that condition; in the former case.

FIG. 6.

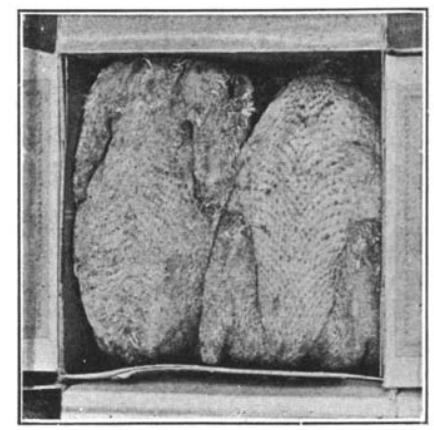

Pasteboard carton for two chickens with the lid removed. The wide border is formed of portions of four similar cartons with closed lids.

it is sold as "fresh," while in the latter case even if held for only a few weeks it is termed "storage." If a chicken be scalded or water-cooled, it will deteriorate rapidly even when hard frozen. If a bird be in the incipient stages of decomposition when hard frozen, deterioration will progress while in that state and decomposition will be rapid after thawing. Only dry picked, dry chilled poultry should be put into cold storage. Since the freezing should be rapid, the containers should be comparatively small, barrels should be avoided and boxes should be used. In order to exclude air from the birds, recourse is had to tight packages. Each chicken is wrapped in parchment paper when the stock is high grade; the result is two fold, the birds cannot rub against each other, and they cannot freeze into a solid mass. The packer usually ships poultry, which is to be stored, in a 
refrigerator car to a cold storage warehouse; all possible precautions against bad treatment are taken. At the warehouse the boxes of poultry are kept in a room with mechanical refrigeration, at $-10^{\circ} \mathrm{F}$. $\left(-23^{\circ} \mathrm{C}\right.$. $)$ for several days, until the chickens are completely frozen. The boxes are then transferred to another room with a temperature of $10^{\circ} \mathrm{F} .\left(-\mathrm{I} 2^{\circ} \mathrm{C}\right.$. $)$ where they are kept until placed on the market.

Only poultry of good quality should be stored. If the chicken be poorly dressed, e.g., scalded or water-cooled, or if it be in the early stages of decomposition, its quality will not be improved by its storage in the frozen state. In fact even the best of poultry is not improved by being kept frozen for any length of time. About the sixth month of carrying the sense of taste of a careful observer reveals a difference between frozen poultry and that freshly killed. However, up to nine months, the difference is so slight that it is of scarcely more than scientific interest. After nine months the flesh is undoubtedly wholesome and nutritious but a loss in flavor has occurred, proportionate to the period of storage.

It is highly desirable that frozen poultry be sold at retail in the frozen state, and that thawing occur in the ice box of the consumer. If the chicken be frozen by the packer, it should be allowed to "ripen" for several days in the ice box, or it will have a flat flavor. If the poultry has been several days in transit to the storage warehouse, and has been merely chilled prior to its arrival at that place, as soon as the bird has thawed in the ice box, it will be found to possess a good eating quality. Birds should not be thawed commercially by placing them in cold water, for such a procedure not only gives rise to rapid decomposition, but also removes a considerable portion of the flavor. Since the flavor is the first attribute of the fresh chicken to disappear during storage in the frozen state, care should be taken to retain the flavor in frozen birds, therefore thawing in water should be avoided. Thawing is best carried out by hanging the chickens in cool air, which is kept at the temperature of an ordinary ice refrigerator, the air should be circulated, to evaporate any moisture, which may settle upon any of the birds. Twenty-four hours should suffice for thawing a chicken of ordinary size, though a large roasting chicken may require a slightly longer period of time. 
"So thawed, a bird well prepared and stored for a reasonable length of time-that is, from one season of production until the next as a maximum-will have a clear, fresh color in the skin, which will be soft in texture, slipping easily from the muscles beneath it. The flesh of breast and thighs may be very slightly deeper in color than in the fresh specimen, but so little that the change is negligible from a practical view-point. The fat is generally a little deeper in color and may have a slight taste and odor of rancidity."

After frozen poultry has been thawed and placed on the market, it should never be returned to the freezer. Refreezing is never a success, for loss in quality occurs after a second thawing. While the refreezing of poultry thawed in air is decidedly deleterious, that which is thawed in water and refrozen is in a much worse condition.

SCIENTIFIC STUDY OF COMMERCIAL METHODS IN THE l'IELD.

In a scientific study of poultry handling, it is necessary to trace the history of a chicken from the time it arrives at the packing house until it finally reaches the consumer. The mode of killing, dressing and chilling must be known, a record must be kept of the transportation, and the bird must be followed through its stay-be it long or short-at the warehouse until it passes into the hands of the retail dealer, and then of the consumer.

A branch- or field-laboratory is installed in the packing house, so that a quantitative analysis, both chemical and bacteriological, may be marle of the sample after the chilling process has ended and the birds are about to be packed. Visual "inspections" of such properties as odor, color of skin, etc., are made during the marketing as are also chemical and bacteriological analyses. It is impossible to express visual inspections in quantitative terms, and moreover such observations are influenced to a great extent by the personal equation of the observer. Chemical and bacteriological analyses are very delicate and accurate, are quantitative and are much less dependent upon personal equation.

A brief description of the research, upon the comparative rate of decomposition of undrawn poultry and that which had been drawn in various ways, will give an idea of the nature of the field work of this laboratory. Targe mature hens were

Vol. CLXXII, No. IO28-I4 
killed by cutting the blood-vessels of the neck from within the mouth, and the brain was also punctured. They were well-bled, dry-picked, air-chilled; some were undrawn, others were eviscerated entirely or partially by the various methods of drawing (wire, Boston, full) which have been described in the preceding chapter. From their entrance to the chill room until their withdrawal from the retailer's for final analysis, the chickens were accompanied by a thermograph in order to obtain a complete record of the temperature. The birds were exposed for from twenty-four to forty-eight hours in a chill room which had a temperature between $27^{\circ}$ and $4 \mathrm{I}^{\circ} \mathrm{F}$., with an average of $34^{\circ} \mathrm{F}$. A sample was then analyzed; the other fowls were wrapped, boxed and placed in a refrigerator car, if a car lot was ready for shipment; otherwise they were held in a freezer at about $12^{\circ} \mathrm{F}$. for three days on an average until a car was loaded.

The experimental packages formed part of an actual commercial shipment from the packing house. They were placed in the centre of the car, not more than four feet above the floor; the bunkers were filled with salt and ice, and instructions for icing en route accompanied the car. A period of seven and one-half days was usually required for the railroad haul of about 1700 miles. When the car arrived at its destination, the boxes were transferred to the chill room of the wholesale dealer, which had an average temperature of $32.6^{\circ} \mathrm{F}$. The chickens were inspected and a sample taken for analysis. From the wholesaler the boxes were removed by wagon-a short haulto the retail dealer. Since the equipment and methods of retailers vary within wide limits, arrangements were made for several of these dealers to participate in the research. They used the ice box for refrigeration. Whenever a display was made, the birds were hung in the shop window. The average temperature, including that of the window display, was $48^{\circ}$ F. Inspections were made and samples removed for analysis when the retailer had sold at least one-half of his stock from the car lot of which the experimental packages had formed a part, and again "at the very last of the marketing or a little later than the retailer's regular sales, if the general market happened to be dragging." These samples, two from the retailer and one from the wholesaler, were submitted in this laboratory 
to chemical and bacteriological analysis, including the determination of the acidity of the crude abdominal fat (as a measure of fat decomposition), the quantity of loosely-bound or ammoniacal nitrogen in the flesh (as a measure of protein decomposition), and the number of bacteria per gramme in the abdominal wall.

In these experiments all disturbing factors such as bad bleeding, had been eliminated. The birds differed only in mode of drawing; they had been subjected simultaneously to the same definite conditions of killing, picking, chilling, transportation and final marketing, therefore any differences between the chickens entirely or partially eviscerated and the undrawn birds, must be ascribed entirely to the method of drawing. A series of eleven shiptnents were included in this research which extended over a period of six months from January to June. From the average results of the analyses of the samples comprising these eleven experimental shipments, the following conclusions follow. Throughout the entire marketing period, the acidity of the crude abdominal fat increased progressively in all the samples, undrawn, wire, Boston and full drawn. The increase in acidity was greatest in the full drawn birds, in fact even in the packing house they had a slightly higher acid value than the other samples.

During the marketing, especially during the sojourn at the retail dealer's, the ammoniacal nitrogen in the flesh underwent a progressive increase, which was greatest in the full drawn chickens.

The number of bacteria in the abdominal wall also increased progressively. During the entire period, the undrawn birds contained the fewest and the full drawn the greatest number of organisms per gramme.

At the warehouse of the wholesale dealer or commission man, differences in quality due to mode of drawing were scarcely revealed by visual inspection. However, during the period of retail marketing, these differences became visible to a marked degree. Though stale, the last samples of undrawn chickens were still edible with a single exception; the wire drawn fowils were close to the undrawn; the Boston drawn birds were of a distinctly lower grade and occasionally were no longer edible. The full drawn chickens were always in the worst condition and frequently were no longer fit for food. 
As already stated, the delicate and accurate methods of quantitative chemical and bacteriological analysis detect differences in quality due to mode of dressing even at the wholesaler's. These quantitative methods demonstrate that deterioration is progressive and is most rapid in the full drawn fowls and least rapid in the undrawn. The wire drawn and Boston drawn birds lie midway between the undrawn and full drawn; the wire drawn, which are more like the undrawn, are usually the better.

\section{IIARD FROZEN POULTRY.}

The changes which occur in hard frozen poultry have already been mentioned in Part $l$. The flesh undergoes a desiccation with consequent increase in total solids and decrease in water content. The protein suffers a slow and specialized proteolysis, similar to that produced by the enzyme trypsin. The fat increases in acidity, and the saponification number and Hehner number change in the same direction simultaneously. The changes in the flesh, which are revealed by histological study, suggest an autodigestion. The bacteria which proliferate at $20^{\circ} \mathrm{C}$., tend to increase. These changes, however, are chiefly of scientific interest. If a bird be given the proper treatment before, during and after storage in the frozen condition (as described in the chapter on Commercial Methods), it may be stored for a reasonable length of time, with the period from one season of production to the next as a maximum, without loss in food value.

CHFMICAL CHANGE AND BACTERIOLOGICAL GROWTH IN MILK

AT LOW TEMPERATURES.

Milk has been kept at or a little below a temperature of $0^{\circ}$ C. for periods ranging from a few days to almost two years. Under these conditions the casein undergoes a rapid digestion until finally more than fifty per cent. of it has changed to soluble compounds, and an increase in caseoses, amino acids and probably peptones occurs apparently at the cost of the digested casein. The proteolysis is pronounced at the end of two weeks, although it may vary in rapidity in different samples. The acidity of the milk increases at low temperatures and after several weeks is much higher than is required to produce a 
Handling, Transportation, and Storage of Foodstuffs. I 87

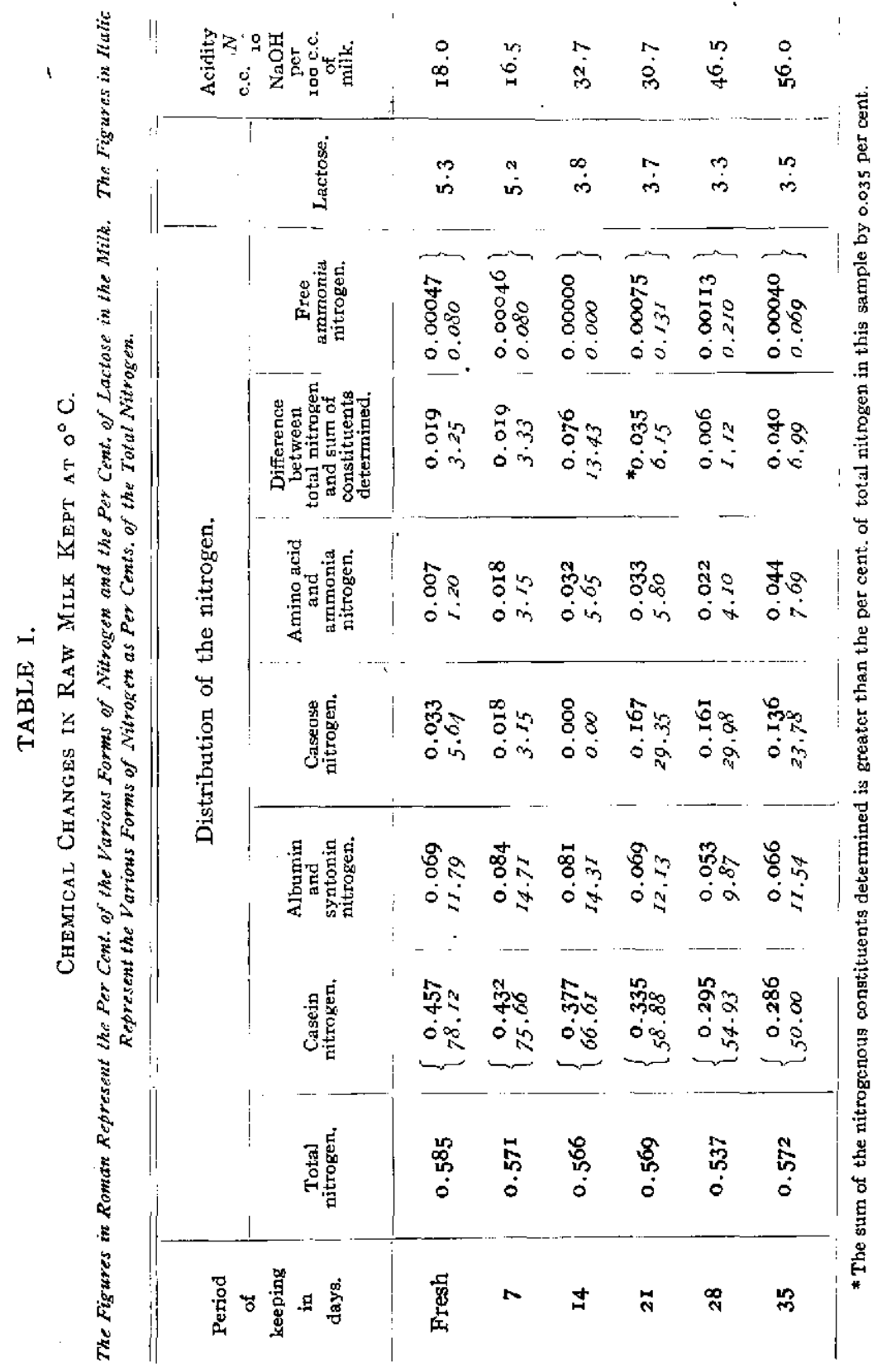


curd spontaneously at ordinary temperatures; yet the phenomenon of curdling rarely occurred, in fact milk with an acidity as high as IOI c.c. of $\frac{N}{\text { Io }}$ sodium hydroxide to IOO c.c. of milk did not form a curd even after exposure to the temperature of an ice box for days. A decrease in the lactose content also cccurred. Table I shows the chemical changes undergone by a raw milk kept at $0^{\circ} \mathrm{C}$. for 5 weeks, and analyzed when fresh and at intervals of one week thereafter.

Bacterial growth in milk stored at low temperatures was pronounced at the end of a week, even in the cleanest milk. The organisms always increased in number for five or six weeks and reached a maximum of hundreds of millions and occasionally of over a billion to the cubic centimetre. This enormous increase in bacterial content occurred in spite of the fact that the milk had been converted into a semi-solid mass of ice crystals by prolonged exposure to a temperature of $29^{\circ}$ to $3 \mathrm{r}^{\circ}$ F. Howcver neither odor nor taste indicated the presence of the enormous number of organisms, and the milk did not curd even on heating; in fact to the ordinary observer it was still suitable for houschold use, until the bacterial content began to decrease and the organisms of putrefaction made their presence known. Neutral organisms were present as well as those which form acid and those which act on protein. The liquifying organisms were more numerous and the acid forming bacteria were present in relatively smaller numbers than in milk kept at higher temperatures. "Certain species such as $B$. formosus, $B$. solitarius, and $B$. Ravenel, were especially resistant to cold and frequently were the predominating species, or almost in pure culture at the close of the experiment."

"A very marked difference in both the number and kind of organisms which developed on the plates was noticed, depending upon the temperature at which the plate was incubated. In certain experiments the maximum number grew at $37^{\circ} \mathrm{C}$. In others the temperature at which the milk was stored served best for colony formation. The relative number of organisms growing at $37^{\circ} \mathrm{C}$, $20^{\circ} \mathrm{C}$, and $0^{\circ} \mathrm{C}$, or a little below, varied greatly also with the length of time that the milk had been kept in storage, the organisms developing at body temperature being ordinarily greatly in excess at the beginning of the experiment 
and diminishing until near its close, when a sharp rise was apt to take place."

When very fresh milk was kept in the laboratory at a temperature of $18^{\circ}$ to $22^{\circ} \mathrm{C}$., bacterial growth was rapid and profuse; the acid forming organisms were in high proportion and the liquifying organisms were relatively lower. The milk ordinarily curdled when the acidity had risen to between 23 c.c. and 28 c.c. of $\frac{N}{10}$ sodium hydroxide per soo c.c. of milk. At this point only about one per cent. of the casein had been digested with the formation of soluble products.

STUDIES OF EGGS.

In the chemical study of eggs it became necessary to devise certain analytical methods. Thus the separation of white and yolk of raw eggs offered difficulties which were overcome in the following manner: the shell was broken, the white was poured off as completely as possible, and the yolk was washed free from white while still in the shell, by means of a gentle stream of water directed from a wash bottle. The yolk was then transferred to a sheet of filter paper and rolled about gently until dry; the vitelline membrane was not broken. White and yolk were analyzed separately, each became the object of a general or gross analysis. In addition the various forns of protein in the white were determined, and the fat in the yolk was extracted and studied. Since the fat could not be extracted directly from the liquid yolk by means of petroleum ether in a Soxhlet extractor, the yolk was first coagulated with alcohol, then extracted in the usual way. In like manner a technic was devised for the determination of the number and species of organisms in both the white and yolk.

An article upon the chemical composition and bacterial content of fresh eggs has already been published, and further studies of various phases of the egg industry are now in progress.

Fresh eggs of the Barred Plymouth Rock and White Leghorn breeds were studied separately. The eggs were laid by well-fed hens, the Plymouth Rock during September, October, and March; the Leghorn during February and March, "It is of interest to note that for these well-fed hens there is practically no difference in composition between Fall and Spring eggs." 
Practically no difference in the chemical composition of the white was found between fresh Leghorn and Plymouth Rock FIG. 7 .

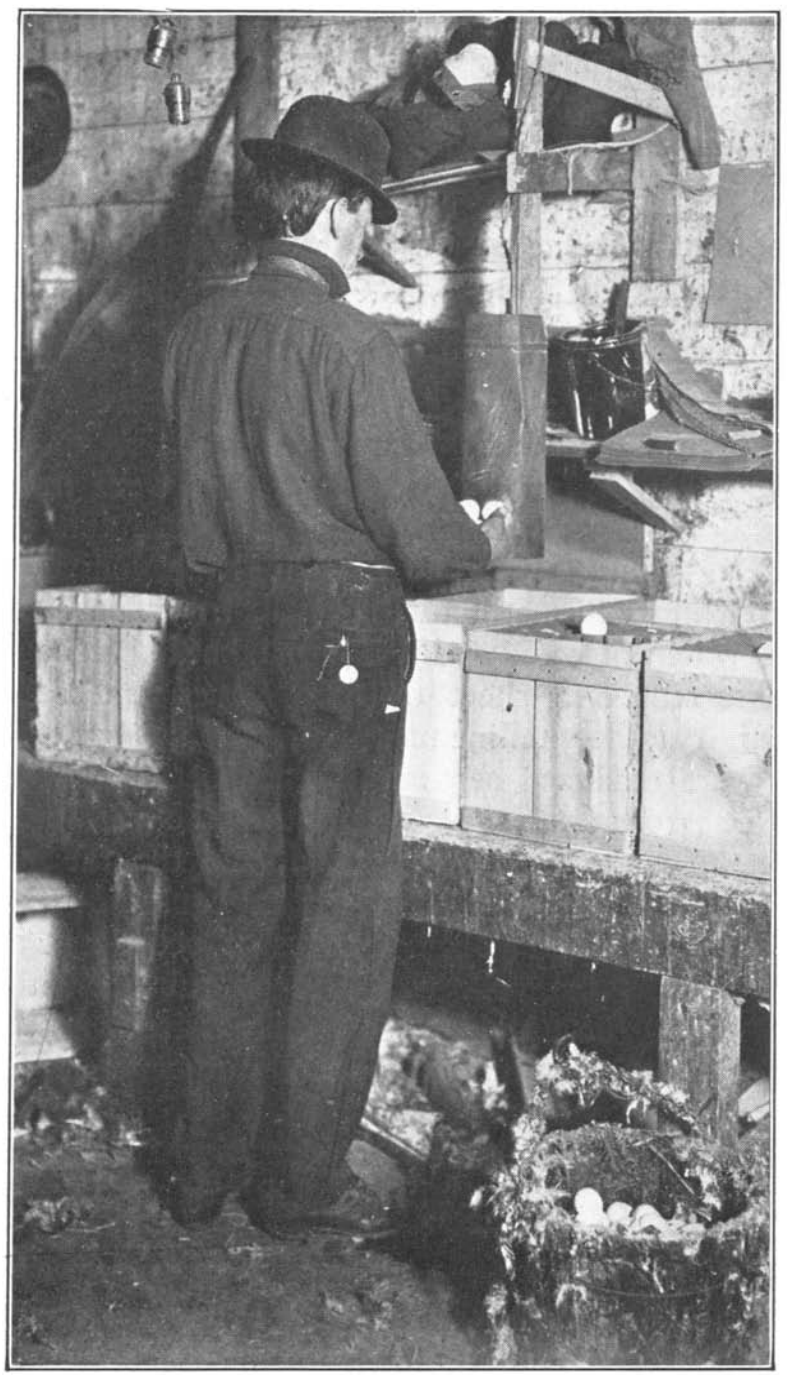

Candling eggs commercially in a packing house. The operator is holding the eggs before the view-holcs oi the electric egg-candle. The bucket at his feet is for the reception of " rots" and "spots." The scientific principles of this form of optical apparatus are discussed in Part I of this peper, JoURNAL OF THE FrankLIN INSTITUTE, June IgIt, cl XXi. 593.

eggs. Although the gross composition or general analysis of the yolk was influenced but slightly by either breed or individual 
samples, yet the yolk fat of both breeds was subject to wide variations in the values of the fat constants. Organisms were usually present in both. white and yolk of these fresh eggs. "In the 57 experiments 18 had a decidedly greater number of bacteria in the yolk; I I had the majority in the white and 2 I had an almost even distribution; 7 were sterile." From roo eggs, 36 species of bacteria, 3 varieties of molds and 2 varieties of yeast were isolated.

The commercial methods for the transportation and refrigeration of eggs have already been described in a previous publication of this laboratory. ${ }^{1}$

It is interesting to note that the chemistry of the egg received attention during the early days of American science. On May 19, I794, John Redman Coxe presented to the Provost, the Trustees and Medical Faculty of the University of Pennsylvania, for the Degree of Doctor of Medicine, "An Inaugural Essay on Inflammation," in which he states, on page 30 , that the experiments made by himself and others "prove that portion of air which we always find in one end of the egg to be oxygenous gas." 2

\section{CONCLUSION.}

Modern science is showing a decided trend toward the conservation of natural resources - animal, vegetable and mineraland of the public health. In this work of conservation, the various scientific bureaus of the Federal Government all have a part; the work of a few of these bureaus may be briefly reviewed. The Public Health and Marine Hospital Service of the Department of the Treasury guards the health of the nation. In the Department of the Interior several bureaus are engaged in conservation; the Reclamation Service carries out the work of irrigation; the Geological Survey studies mineral resources and water resources; and the Bureau of Mines has a two-fold function, the conservation of mineral wealth including fuels, and the conservation of life among mine workers, i.e., the causes and methods of prevention of mine accidents. In the Department

${ }^{1}$ Pennington, U. S. Department of Agriculture, Bureau of Chemistry, Circular No. 64, rg10.

${ }^{3}$ The Library of the University of Pennsylvania contains a copy of Coxe's Essay, printed at Philadelphia by R. Aitken \& Son, I794. 
of Agriculture the work of the Bureaus of Animal Industry, Forestry, Plant Industry, and Chemistry, among others, is in large part one of conservation. Thus the Bureau of Animal Industry carries out the meat inspection law, and stamps out contagious diseases of animals, such as the recent outbreak of hoof-and-mouth-disease in Pennsylvania and neighboring States. The Forest Service labors for the conservation of the timber supply. One phase of the work of the Bureau of Plant Industry is the study of the vegetable food supply. New vegetables are introduced; and methods of handling the vegetables and fruits already raised in this country are studied, so that they may pass from the producer to the consumer with least loss from decay or deterioration in quality during their journey. This work is illustrated by the investigation on the marketing of citrus fruits.

The Bureau of Chemistry enforces the Food and Drugs Act and carries out various investigations in the fields of bromatology and pharmacy, among which is the work of the Food Research Laboratory. The work of this laboratory has been described in the preceding pages. The course of perishable animal foodstuffs is followed from the producer to the consumer; during these studies the hearty co-operation is secured of packers, railroads, commission merchants, and retail dealers. The various problems which arise are solved by the application of the research methods of the physical sciences-chemistry and physics-and the medical sciences-physiological chemistry, bacteriology and histology. The various factors which influence the keeping qualities of perishable foodstuffs during their marketing are studied in detail; and methods are discovered which will improve the quality of the product as it reaches the consumer, and which will reduce the loss in marketing to a minimum. This is truly conservation of the nation's food stpply!

\section{BIBLIOGRAPHY.}

The contributions from the Food Research Laboratory which have served, in large part, as the basis of Parts I and II fall into four divisions:

I.-Papers on Poultry. Yearbook of the United States Department of Agriculture, 1907, 197-206. U. S. Department of Agriculture, Bureau of Chemistry, Bulletin No. 115, 1908, 57-107. Premier Congrès International du Froid, Rapports et Communications, Paris, I908, 1I, 216-260. Journal of the American Chemical Society, I910, xxxii, 561-568, 568-572. U. S. Depart- 
ment of Agriculiure, Burean of Chemistry. Circular No. Gr, rgro; Circular No. 64, I9I0; Circular No. 70, I9II. "The Keeping Quality of Poultry," by Pennington. Address made at the Annual Meeting Missouri Carlot Shippers of Eggs, Butter and Poultry, March, I9Io. Published by the Association. Secretary's office, St. Louis.

II.-Papers on eggs. Journal of Biological Chemistry, 1910, vii, 109-1 32. Seventh International Congress of Applied Chemistry, London, 1909, Section vii. Agricultural Chemistry, 228.

III.-Paper on milk. Journal of Biological Chemistry, 1908, iv, 353-393.

IV.-Papers on fats. Journal or the Franklin Institute, 1909, cixviii, 365-384, 421-456; 1910, clxix 23-54. Seventh International Congress of Applied Chemistry, London, Igo9, Section viiic. Bromatology, 268-27I.

Note.-Part I, "The Function and Equipment of the Laboratory and a Résumé of the Researches Carried Out Therein," appeared in the Journal of tile Franislin Institute, June, igi cl clxxi, 585-598. Part III, "Select Methods of Analysis" will appear in an early issue of the Journal.

Gasolene Electric 'Bus for London. (Amer. Mach., xxxiv, 785.) - A new type of motor bus is about to be introduced in London, of the combined gasolene-electric type. Two independent I2 horsepower, four-cylinder gasolene motors each drive, through an electric "dynomotor" and a flexible shaft, one of the rear whecls of the vehicle, When the load is light, the excess power of the engines is absorbed by the dynamotors, as dynamos, to charge a special 560 pound storage battery. When the load is heavy the dynamotors are automatically changed into electromotors, and assist the engines, taking power from the batteries. By this arrangement not only are the starting and control much smoother and quieter, but by the more constant load on the engines, the fuel economy is improved. The vehicles, including the wheels, are constructed of steel.

Magnolia Antifriction Metal. (Amer. Machinist, xxxiv, 798.) -According to the Brass World, the proportions used to make Magnolia metal are lead 80 pounds, antimony is pounds, and tin 5 pounds. The analysis shows lead 78.27 per cent., antimony 17.81 per cent., tin 3.88 per cent. and copper 0.04 per cent. The copper is present as an impurity.

Sulphur and Sulphuric Acid in the United States. (Oil, Paint and Drug Rep., May r, I9II.) -A report of the Geological Survey Department shows that the output of sulphur in the United States has risen from 3147 tons, valued at $\$ 88,100$, in 1900 , to 239,312 tons, valued at $\$ 4,432,066$ in I9Io. The United States still imports some sulphur, but exports about the same amount. A little comes in from Japan, but the business is not well established. A large 